\author{
Arkadiusz JAMROZIK ${ }^{1}$ \\ Michał PYRC ${ }^{2}$ \\ Marta ŚWIĄCIK ${ }^{3}$ \\ Magdalena SCHAB ${ }^{4}$
}

\title{
OCZYSZCZANIE I PRZETWARZANIE GAZU GENERATOROWEGO ZE ZGAZOWANIA ODPADÓW
}

\begin{abstract}
Energia uzyskiwana $\mathrm{z}$ odpadów jest nie tylko cennym źródłem energii odnawialnej, ale także niezwykle przydatną i opłacalną metodą redukcji ilości odpadów składowanych na wysypiskach śmieci. Jedną z metod neutralizacji i energetycznego wykorzystania odpadów jest technologia zgazowania i wykorzystania pozyskanego gazu generatorowego do zasilania silników spalinowych w zespołach prądotwórczych. W przypadku wykorzystania gazu generatorowego do zasilania silnika tłokowego należy mieć na uwadze stosunkowo ostre wymagania w zakresie czystości gazu. Podstawowym problemem, występującym w układach zgazowania są substancje smoliste, które kondensując, osiadają na powierzchniach wewnętrznych kanału dolotowego silnika, blokując przepływ oraz na elementach układu rozrządu uniemożliwiając poprawną pracę silnika. Ponadto smoła pogazowa i zawarte w niej związki chemiczne mogą powodować korozję i erozję ścian cylindra silnika. W artykule scharakteryzowano proces zgazowania jako przykład termicznej neutralizacji odpadów oraz proces oczyszczania gaz generatorowego ze zgazowania. Zaprezentowano uruchomioną w Instytucie Maszyn Cieplnych Politechniki Częstochowskiej instalację oczyszczania gazu generatorowego uzyskanego ze zgazowania osadu ściekowego będącego ubocznym produktem procesu oczyszczania ścieków komunalnych w oczyszczalni. W instalacji zgazowania osadu ściekowego do układu oczyszczania gazu użyto filtrów cyklonowych wraz z odpylaczami mokrymi nazywanymi skruberami Venturiego. Instalacja oczyszczająca zapewniła oddzielenie smół pogazowych zawartych w osadzie w stopniu eliminującym kondensację tych smół w układzie dolotowym badawczego doładowanego silnika tłokowego napędzającego generator prądotwórczy.
\end{abstract}

Słowa kluczowe: zgazowanie, gaz generatorowy, osad ściekowy, instalacja oczyszczania gazu, silnik spalinowy

\footnotetext{
${ }^{1}$ Autor do korespondencji: Arkadiusz Jamrozik, Instytut Maszyn Cieplnych, Politechnika Częstochowska, Armii Krajowej 21, 42-201 Częstochowa, jamrozik@imc.pcz.czest.pl

${ }^{2}$ Michał Pyrc, Instytut Maszyn Cieplnych, Politechnika Częstochowska, Armii Krajowej 21, $42-$

201 Częstochowa, pyrc@imc.pcz.czest.pl

${ }^{3}$ Marta Świącik, Politechnika Częstochowska, martus1a92@o2.pl

${ }^{4}$ Magdalena Schab, Politechnika Częstochowska, graschab@wp.pl
} 


\section{Wstęp}

Światowe zapotrzebowanie na energię ciągle rośnie. Jest to szczególnie widoczne w regionach rozwijających się, w których obserwuje się szybko postępującą urbanizację oraz ciągłe bogacenie się społeczeństwa. Aktualnie większość energii na świecie pochodzi z paliw kopalnych tj. węgiel, ropa naftowa czy gazu ziemny. Jednak według Dyrektywy Unijnej nr 2009/28/WE, do 2020 roku, udział energii odnawialnej w całkowitym zużyciu energii powinien wynieść 20\% (tzw. Pakiet 3x20). Dla każdego państwa członkowskiego ustanowione są cele strategiczne w tym zakresie (projekt Dyrektywy UE 2008/0016), dla Polski udział ten wynosi 15\% [1-3].

Za źródło o największym potencjale technicznym na podstawie danych pochodzących ze Strategii Rozwoju Energetyki Odnawialnej opracowanej przez Ministerstwo Środowiska uznaje się biomasę. Najnowsza definicja biomasy została zawarta w Dyrektywie Parlamentu Europejskiego i Rady 2009/28/WE z 23 kwietnia 2009 roku [4]. Pod pojęciem biomasy (art. 2 pkt. e) określono ulegające biodegradacji frakcje produktów, odpadów i pozostałości pochodzenia biologicznego z rolnictwa (łącznie z substancjami roślinnymi i zwierzęcymi), leśnictwa i związanych z nimi działów przemysłu, w tym rybołówstwa lub akwakultury, a także ulegające biodegradacji frakcje odpadów przemysłowych i miejskich. Spośród odpadow miejskich coraz częściej do energetycznego przetwarzania wykorzystuje się organiczne osady ściekowe, będące ubocznym produktem procesu oczyszczania ścieków komunalnych w oczyszczalni [5].

\subsection{Biomasa oraz potencjał energetyczny procesu jej zgazowania}

Zalety zgazowania biomasy, w odniesieniu do innych metod jej energetycznego wykorzystania, to:

- możliwość różnorodnego wykorzystania powstałego gazu: produkcja energii cieplnej i elektrycznej, jako surowiec w produkcji paliw w katalitycznych procesach syntezy oraz wytwarzanie SNG ( Substitute Natural Gas) - zastępczego gazu ziemnego;

- niska emisja szkodliwych związków;

- większa sprawność wytwarzania energii;

- możliwość stosowania surowej biomasy o dużym stopniu zawilgocenia.

Do głównych surowców wykorzystywanych podczas procesu zgazowania biomasy należą: słoma; drewno $\mathrm{z}$ odpadów z procesów technologicznych; odpady z produkcji rolnej i leśnej; rośliny z upraw energetycznych; odpady z hodowli zwierząt oraz frakcja biomasy pochodząca z odpadów komunalnych, np. osady ściekowe.

Podstawowe, charakterystyczne cechy biomasy stanowiącej surowiec do zgazowania to: skład elementarny, wartość opałowa, gęstość (ciężar nasypowy), wilgotność i zawartość popiołu [6]. 


\subsection{Technologia zgazowania biomasy}

Proces zgazowania składa się z poszczególnych procesów cząstkowych. Pierwszym etapem jest suszenie mokrej biomasy, aż uzyska poziom wilgoci nie przekraczający $10-15 \%$. Następnie zachodzi reakcja pirolizy, podczas której wyodrębniają się substancje lotne, a przy zwiększeniu temperatury utleniają się frakcje lotne. Dzięki temu powstaje $\mathrm{CO}, \mathrm{CO}_{2}$ i para wodna. Przejście uzyskanych frakcji lotnych przez warstwę rozżarzonego surowca powoduje zajście procesów redukcji, podczas których otrzymujemy $\mathrm{CO}, \mathrm{H}_{2} \mathrm{i} \mathrm{CH}_{4}$.

Podstawowe parametry procesu zgazowania to: temperatura, ciśnienie, szybkość podawania reagentów, warunki powierzchniowe, szybkość przepływu gazu oraz obecność katalizatora. Wpływ temperatury i ciśnienia na przebieg poszczególnych reakcji procesu zgazowania biomasy, czyli na skład wytworzonego gazu możemy przewidzieć przez analizę produktów reakcji.

Najważniejszym elementem zgazowarki jest gazogenerator, nazywany też komorą bądź reaktorem zgazowania. To w nim właśnie zachodzi szereg reakcji fizyko-chemicznych, w wyniku których powstaje gaz. Gazogeneratory dzielimy według następujących kryteriów:

- czynniki zgazowujące: tlen, powietrze, para wodna, dwutlenek węgla oraz ich mieszaniny;

- sposób dostarczenia ciepła do procesu: allotermiczne, autotermiczne, ogrzewane pośrednio i bezpośrednio;

- parametry procesu: ciśnienie i temperatura;

- konstrukcje reaktorów: ze złożem stałym, fluidalnym oraz strumieniowe.

Od tego, w jaki sposób będzie wykorzystany gaz zależy wybór technologii zgazowania. Spalając bezpośrednio gaz w kotłach i w instalacjach technologicznych można pozwolić na zastosowanie najtańszej technologii o niskich wy-

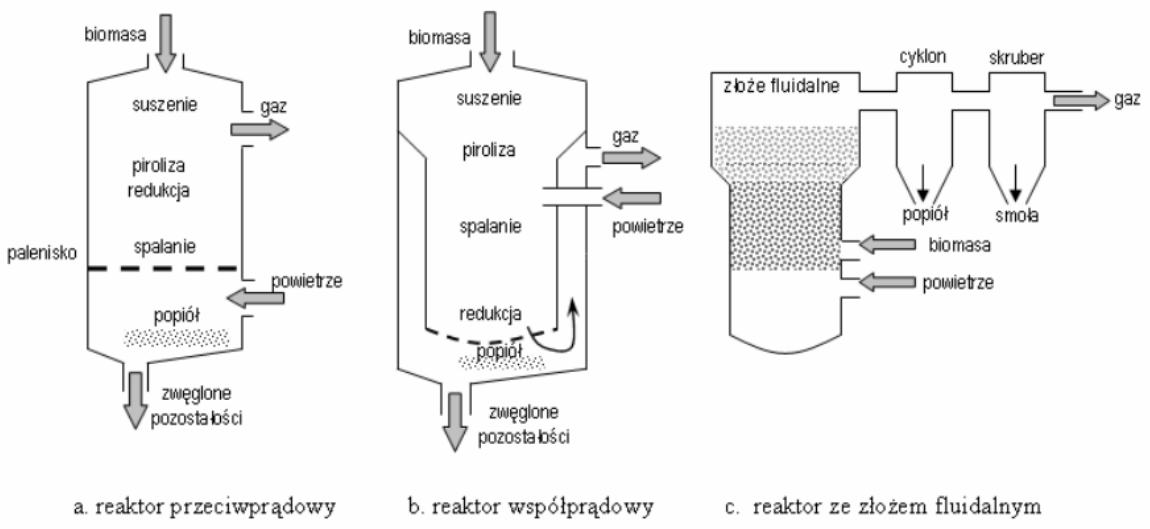

Rys. 1. Wybrane typy reaktorów zgazowania biomasy, na podstawie [7]

Fig. 1. Selected types of biomass gasification reactors, based on [7] 
maganiach jakości biomasy, zazwyczaj z zastosowaniem reaktorów ze złożem stałym, przeciwprądowym, gdyż wtedy wymagania wobec gazu oraz sposobu pracy generatora są najmniej restrykcyjne. Kiedy chcemy przeprowadzić zgazowanie dla uzyskania gazu syntezowego, należy zastosować reaktory ze złożem fluidalnym, zapewniając odpowiednie moce, dyspozycyjność układu i czystość gazu. Jeżeli otrzymanym gazem mają być zasilane turbiny gazowe, stosowane są reaktory ze złożem fluidalnym bądź reaktory strumieniowe. Podczas zasilania silników tłokowych stosuje się zazwyczaj układy ze złożem stałym, głównie dolno-ciągowe.

\subsection{Skład surowego gazu generatorowego oraz możliwości jego wyko- rzystania}

Gaz uzyskany ze zgazowania odpadów może być spalany bezpośrednio w kotle parowym. Otrzymana w ten sposób para może służyć do napędu turbiny w elektrociepłowni. Gaz generatorowy może także znaleźć zastosowanie w turbinie gazowej bądź w układach kogeneracyjnych z silnikami tłokowymi. Gaz ten można również zamieniać w ogniwach paliwowych na energię elektryczną.

Na skład surowego gazu generatorowego wpływ ma wiele czynników tj. czynnik zgazowujący, parametry procesu zgazowania odpadów, konstrukcja gazogeneratora oraz skład surowców.

Można zauważyć, że w przypadku zgazowania powietrzem w uzyskanym gazie znajdują się duże ilości azotu, co obniża wartość jego ciepła spalania. W przypadku gdy czynnikiem zgazowującym jest para wodna, następuje zwiększenie stężenia wodoru $\mathrm{w}$ gazie, co ma dalsze znaczenie w procesie metanizacji. Poza czynnikiem zgazowującym, na skład gazu wpływ ma także temperatura procesu. Wraz z jej wzrostem dochodzi do spadku zawartości metanu w gazie.

Tabela. 1. Przykładowy skład gazu z procesu gazyfikacji na złożu stałym, na podstawie [8]

Table. 1. Composition of producer gas taken from fixed bed gasifier, based on [8]

\begin{tabular}{|l|c|c|c|}
\hline \multicolumn{1}{|c|}{ Składnik } & Wymiar & $\begin{array}{c}\text { Gazogenerator } \\
\text { przeciwprądowy }\end{array}$ & $\begin{array}{c}\text { Gazogenerator } \\
\text { współprądowy }\end{array}$ \\
\hline $\mathrm{CO}$ & $\%$ & $15-20$ & $10-22$ \\
\hline $\mathrm{H}_{2}$ & $\%$ & $10-14$ & $15-21$ \\
\hline $\mathrm{CO}_{2}$ & $\%$ & $8-10$ & $11-13$ \\
\hline $\mathrm{CH}_{4}$ & $\%$ & $2-3$ & $1-5$ \\
\hline $\mathrm{N}_{2}$ & $\%$ & pozostałość & pozostałość \\
\hline $\mathrm{H}_{2} \mathrm{O}$ & $\%$ & $10-20$ & $10-20$ \\
\hline $\mathrm{W}_{\mathrm{d}}$ & $\mathrm{MJ} / \mathrm{m}_{\mathrm{n}}{ }^{3}$ & $3.7-5.1$ & $4.0-5.6$ \\
\hline cząstki stałe & $\mathrm{mg} / \mathrm{m}_{\mathrm{n}}{ }^{3}$ & $100-3000$ & $20-8000$ \\
\hline substancje smoliste & $\mathrm{mg} / \mathrm{m}_{\mathrm{n}}{ }^{3}$ & $10000-150000$ & $1-6000$ \\
\hline
\end{tabular}


W gazie ze zgazowania odpadów niebezpiecznymi zanieczyszczeniami są: smoły, amoniak i związki siarki, które należy oczyścić do bardzo niskiego poziomu. Równocześnie procesy oczyszczania gazu syntezowego nie mogą zmierzać do przekształcenia lub usunięcia obecnego w nim metanu.

W przypadku wykorzystania gazu generatorowego do zasilania silnika tłokowego należy mieć na uwadze stosunkowo ostre wymagania w zakresie czystości gazu. Poza cząstkami stałymi i smołą, producenci silników $[9,10]$ określają dopuszczalne poziomy takich zanieczyszczeń jak [11]:

- związki siarki: mniej niż $2000-2200 \mathrm{mg} / \mathrm{m}_{\mathrm{n}}{ }^{3}$ (w przeliczeniu na $\mathrm{H}_{2} \mathrm{~S}$ ),

- amoniak: mniej niż $50-100 \mathrm{mg} / \mathrm{m}_{\mathrm{n}}{ }^{3}$,

- związki krzemu (siloxany): mniej niż $10-50 \mathrm{mg} / \mathrm{m}_{\mathrm{n}}^{3}$ (odpowiedzialne za formowanie się depozytów w układzie przepływowym silnika),

- związki chloru i fluoru (halogenki): mniej niż $100-400 \mathrm{mg} / \mathrm{m}_{\mathrm{n}}{ }^{3}$ (wpływają na zmniejszenie właściwości smarnych oleju silnikowego).

Tabela. 2. Pożądany skład gazu generatorowego do silników Deutz Energy, na podstawie [9]

Table. 2. Desirable composition of producer gas for Deutz Energy engines, based on [9]

\begin{tabular}{|l|c|c|c|}
\hline Wielkość & Symbol & Jednostka & Wartość \\
\hline Wartość opałowa & $\mathrm{Wg}$ & $\mathrm{MJ} / \mathrm{m}_{\mathrm{n}}{ }^{3}$ & $\geq 14.4$ \\
\hline Dwutlenek węgla & $\mathrm{CO}_{2} / \mathrm{Hu}$ & $\mathrm{Vol} \% / \mathrm{kWh} / \mathrm{m}_{\mathrm{n}}{ }^{3}$ & $<10$ \\
\hline Siarka & $\mathrm{S}$ & $\mathrm{mg} / \mathrm{m}_{\mathrm{n}}{ }^{3} \mathrm{CH}_{4}$ & $<2200$ \\
\hline Siarkowodór & $\mathrm{H}_{2} \mathrm{~S}$ & $\mathrm{Vol} \% / \mathrm{m}_{\mathrm{n}}{ }^{3} \mathrm{CH}_{4}$ & $<0.15$ \\
\hline Chlor & $\mathrm{Cl}$ & $\mathrm{mg} / \mathrm{m}_{\mathrm{n}}{ }^{3} \mathrm{CH}_{4}$ & $<100$ \\
\hline Fluor & $\mathrm{F}$ & $\mathrm{mg} / \mathrm{m}_{\mathrm{n}}{ }^{3} \mathrm{CH}_{4}$ & $<50$ \\
\hline Sum. chlor i fluor & $(\mathrm{Cl}+\mathrm{F})$ & $\mathrm{mg} / \mathrm{m}_{\mathrm{n}}{ }^{3} \mathrm{CH}_{4}$ & $<100$ \\
\hline Amoniak & $\mathrm{NH}$ & $\mathrm{mg} / \mathrm{m}_{\mathrm{n}}{ }^{3} \mathrm{CH}_{4}$ & $<30$ \\
\hline Pył & & $\mathrm{mg} / \mathrm{m}_{\mathrm{n}}{ }^{3} \mathrm{CH}_{4}$ & $<10$ \\
\hline Ziarnistość & & $\mu \mathrm{m}$ & $3-10$ \\
\hline Smoły oleiste $(>\mathrm{C} 5<\mathrm{C} 10)$ & & $\mathrm{mg} / \mathrm{m}_{\mathrm{n}}{ }^{3} \mathrm{CH}_{4}$ & $<3000$ \\
\hline Smoły oleiste( $>\mathrm{C} 10)$ & $\mathrm{mg} / \mathrm{m}_{\mathrm{n}}{ }^{3} \mathrm{CH}_{4}$ & $<250$ \\
\hline Krzem & $\mathrm{Si}$ & $\mathrm{mg} / \mathrm{m}_{\mathrm{n}}{ }^{3} \mathrm{CH}_{4}$ & $<10$ \\
\hline Wilgotność & & ${ }^{2}$ & $<80$ \\
\hline
\end{tabular}

\subsection{Metody oczyszczania gazu powstałego ze zgazowania odpadów}

Wśród zanieczyszczeń dużym problemem są smoły, które kondensując, blokują rurociągi i powodują uszkodzenie silników oraz turbin. Związki azotu, siarki i chloru są źródłem emisji związków regulowanych przepisami, takich jak $\mathrm{NO}_{\mathrm{x}}$ i $\mathrm{SO}_{2}$ i mają także działanie korozyjne. Przebieg oczyszczania gazu generatorowego obejmuje następujące metody: chemiczne (np. katalityczne, selek- 
tywne utlenianie lub katalityczna konwersja smoły) oraz oczyszczanie mechaniczne (skrubery, filtry) i fizyczne (kolumny natryskowe).

Metody chemiczne pozwalają na przemianę niepożądanych składników gazu, takich jak smoły i amoniak, w składniki podnoszące jego wartość energetyczną i chemiczną. W przypadku neutralizacji tych zanieczyszczeń wykorzystuje się katalizatory aktywne stosowane $\mathrm{w}$ samym generatorze oraz $\mathrm{w}$ pomocniczych reaktorach katalitycznych, w których reakcje związków smołowych przebiegają w temperaturach zbliżonych do tych, jakie panują w reaktorze zgazowania. Niekiedy też wprowadza się do nich dodatkowy czynnik utleniający $\left(\mathrm{O}_{2}\right.$ lub $\left.\mathrm{H}_{2} \mathrm{O}\right)$. W procesie krakingu lub hydrokrakingu związki smołowe rozpadają się na lekkie węglowodory lub konwertują do $\mathrm{CO}$ i $\mathrm{H}_{2}$. Ze względu na powstający w reakcji metan, hydrokraking może być bardzo pożądaną lub niepożądaną reakcją, w zależności od dalszego kierunku przetwarzania gazu syntezowego. Katalizatorami stosowanymi do krakingu są kwaśne związki w postaci stałej, np. tlenek glinu, oraz zeolity, heteropolikwasy i siarczanowane tlenki metalu. Innymi metodami usuwania smoły są: kraking termiczny, kraking smół w obecności plazmy lub wymywanie w odpowiednio dobranych rozpuszczalnikach [6]. Stosowane są również metody wykorzystujące wyładowania elektryczne. Są to badania z wyładowaniem koronowym impulsowym, barierowym, wstecznym koronowym, RF i mikrofalowym.

Podczas zgazowania większa część azotu znajdującego sie w odpadach zostaje przekształcona do postaci amoniaku i $\mathrm{N}_{2}$. Istnienie w gazie związków azotu jest niewskazane, ze względu na tworzenie się podczas spalania $\mathrm{NO}_{\mathrm{x}}$. Stosowane się dwie metody usuwania amoniaku: rozkład oraz selektywne utlenianie. Podczas rozkładu amoniaku do $\mathrm{N}_{2} \mathrm{i}_{2}$ nie wytwarzają się żadne zanieczyszczenia. Katalizatorami w tej reakcji są: ruten, azotki, tlenoazotki oraz węgliki. Selektywne utlenianie polega na dodawaniu do gazu ze zgazowania, czynnika utleniającego jak np.: $\mathrm{O}_{2}$, NO lub mieszanina $\mathrm{NO} / \mathrm{O}_{2}$.

Kolejnym zanieczyszczeniem gazu ze zgazowania odpadów jest siarka. Obecność związków siarki w gazie ma działanie korozyjne na eksploatowane urządzenia, poprzez niszczące działanie kwasu siarkowego powstałego w reakcji z tlenem i para wodną. Dla oczyszczania gazu z siarki wykorzystywane są złoża $\mathrm{z}$ tlenkiem metalu. Mieszaniny tlenków manganu z miedzią i wanadem oraz $\mathrm{MnO}$ charakteryzują się wysoką zdolnością eliminowania siarki w temperaturze powyżej $600^{\circ} \mathrm{C}$. W przypadku konieczności głębokiego odsiarczania gazu generatorowego wykorzystuje sie metodę redox z zastosowaniem chelatów żelaza. Pozostałymi metodami usuwania związków siarki są metody aminowe, wykorzystujące absorpcję chemiczną lub procesy Rectisol i Selexol, oparte na absorpcji fizycznej.

Najbardziej powszechną metodę oczyszczania gazu ze zgazowania jest oczyszczanie mechaniczno-fizyczne, które pomimo stosunkowo wysokich kosztów daje dobre rezultaty.

W artykule przedstawiono instalację oczyszczania gazu generatorowego powstałego ze zgazowania osadu ściekowego, którą zaprojektowano, wykonano i uruchomiono w Instytucie Maszyn Cieplnych Politechniki Częstochowskiej. 


\section{Instalacja oczyszczania gazu generatorowego}

Stosując się do obowiązujących ograniczeń w składowaniu odpadów biodegradowalnych, w Instytucie Maszyn Cieplnych Politechniki Częstochowskiej opracowano technologię termicznego przetwarzania przefermentowanych, podsuszonych, organicznych osadów ściekowych, będących ubocznym produktem procesu oczyszczania ścieków komunalnych w oczyszczalni, na energię elektryczną i ciepło. W ramach opracowanej w technologii, wykonano, uruchomiono i zbadano prototypową instalację zgazowania osuszonego osadu ściekowego, instalację oczyszczalnia pozyskiwanego gazu generatorowego i zespół prądotwórczy o nominalnej wartości czynnej mocy elektrycznej $80 \mathrm{~kW}$ napędzany doładowanym silnikiem tłokowym adaptowanym do zasilania dwupaliwowego tym gazem i paliwem płynnym $[12,13]$.

Zastosowany gazogenerator współprądowy ze złożem stałym wytwarzał bogaty w wodór gaz generatorowy o wartości opałowej od 2,42 do $3,19 \mathrm{MJ} / \mathrm{m}^{3}$ zawierający stosunkowo małą ilość pyłu $\left(100-1000 \mathrm{mg} / \mathrm{m}^{3}\right)$ i niskowrzących smół (100$500 \mathrm{mg} / \mathrm{m}^{3}$ ). Ilość tych zanieczyszczeń okazała się jednak znacząco większa od górnych granic wartości dopuszczalnych dla silnika tłokowego (do $50 \mathrm{mg} / \mathrm{m}^{3}$ pyłu i do $100 \mathrm{mg} / \mathrm{m}^{3}$ smoły), dlatego surowy gaz generatorowy nie mógł być doprowadzany do silnika bezpośrednio z gazogeneratora. Przed doprowadzeniem do silnika gaz musiał być schłodzony oraz dokładnie oczyszczony w dodatkowej, dość skomplikowanej, instalacji zawierającej układ filtrów cyklonowych, chłodnic, zraszaczy, osuszaczy i filtrów porowatych [14].

Zbudowana w IMC zgazowarka wytwarza ok. $3,5 \mathrm{~m}^{3} / \mathrm{min}$ gorącego gazu generatorowego o temperaturze do ok. $500^{\circ} \mathrm{C}$. Gaz ten zawiera tlenek węgla, wodór, dwutlenek węgla, metan oraz azot i jest zanieczyszczony następującymi substancjami: pył, smoły pogazowe i para wodna.

Gaz wychodzący ze zgazowarki jest chłodzony w chłodnicy wodno-rurkowej do temperatury poniżej $90^{\circ} \mathrm{C}$ i oczyszczony z zanieczyszczeń. Proces oczyszczania jest realizowany w instalacji oczyszczającej, w skład której wchodzi (rys.2):

- separator cyklonowy,

- chłodnica gazu,

- chłodnica cieczy obiegowej chłodnicy gazu z wentylatorem nadmuchowym,

- skruber systemu Venturi,

- chłodnica cieczy obiegowej skrubera z wentylatorem nadmuchowym,

- filtr z wymiennym wkładem porowatym,

- zbiorniki kondensatu wody,

- pompa cieczy,

- dmuchawa o wydajności $0,06 \mathrm{~m}^{3} / \mathrm{s}$ i sprężu min. $0,5 \mathrm{kPa}$.

Ze względu na agresywny charakter gazu instalacja oczyszczająca wykonana jest ze stali odpornej na korozję, a wszystkie elementy zostały zainstalowane na wspólnej ramie (rys. 3). 


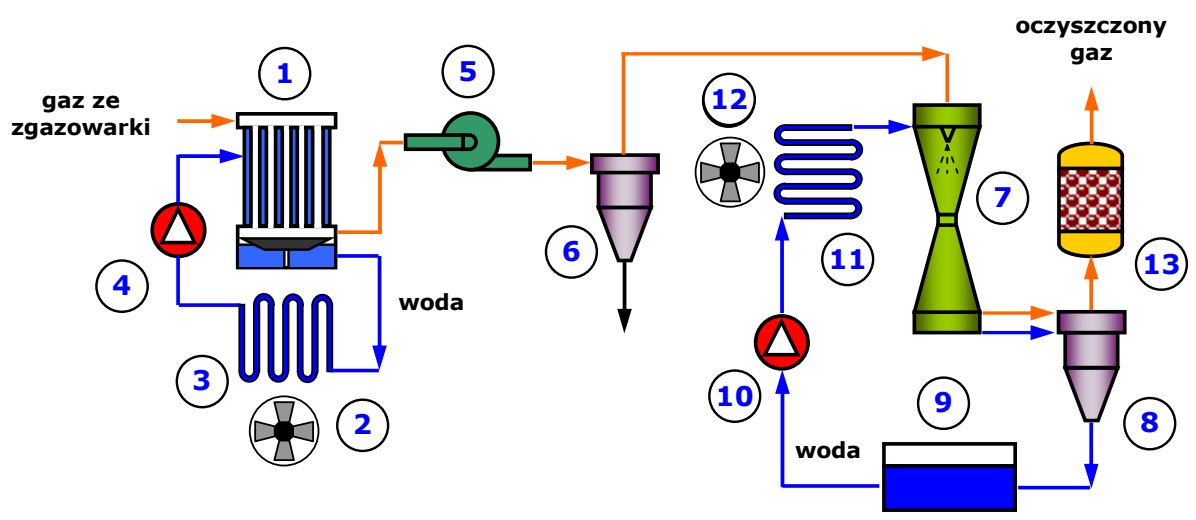

Rys. 2. Schemat instalacji oczyszczającej gaz generatorowy

1 - chłodnica wodno-rurkowa typu U schładzająca gorący gaz generatorowy, 2 - wentylator nadmuchujący powietrze na chłodnicę wody, 3 - chłodnica schładzająca gorącą wodę wypływającą z chłodnicy gazu, 4 - pompa tłocząca chłodną wodę z chłodnicy wody do chłodnicy gazu, 5 - dmuchawa Rootsa, 6 - cyklonowy separator pyłu, 7 - skruber z nastawną dyszą Venturiego, 8 - cyklon separujący krople wody, 9 - zamknięty zbiornik wody rozpylonej w skruberze, 10 - pompa obiegowa tłocząca wodę do chłodnicy skrubera, 11 - chłodnica wody skroplonej w zbiorniku skrubera, 12 wentylator nadmuchujący powietrze na chłodnicę wody, 13 - zbiornik filtra z porowatym wkładem

Fig. 2. Diagram of the generator gas cleaning system

1 - tubular water-cooler type U, cooling hot gas generator, 2 - fan blowing air at the water cooler, 3 - radiator cooling hot water flowing from the gas cooler, 4 - pump pumping cold water from the water cooler to the gas cooler, 5 - Roots blower, 6 - cyclone dust separator, 7 - scrubber with adjustable Venturi nozzle, 8 - cyclone separating water drops, 9 - closed container of water sprayed in the scrubber, 10 - circulating pump pumping the water to the scrubber cooler, 11 - cooler water condensation in the tank scrubber, 12 - fan blowing air at the water cooler, 13 - reservoir with a porous filter cartridge

Podstawowym elementem oczyszczającym gaz generatorowy $\mathrm{z}$ zanieczyszczeń stałych jest cyklon, w którym wykorzystuje się działanie sił odśrodkowych na cząstki stałe i aerozolowe. Cyklon składa się z następujących części: - cylindrycznej, w której zabudowane są: przewód wlotowy oraz wylotowy;

- stożkowej, zakończonej zbiornikiem pyłu.

Między częścią stożkową, a zbiornikiem pyłu zabudowany jest odwrócony stożek, którego zadaniem jest zabezpieczenie pyłu zgromadzonego w zbiorniku przed porwaniem przez strugę gazu.

W klasycznym cyklonie gaz zapylony wprowadzany jest stycznie do obudowy cylindrycznej. Jej kształt powoduje zawirowanie strugi gazu, która ruchem spiralnym przesuwa się w dół urządzenia. Powstająca na skutek ruchu wirowego siła odśrodkowa odrzuca ziarna pyłu zawarte w gazie na ścianki zewnętrzne urządzenia, po których zsuwają się one do zbiornika pyłu. Struga gazu w dole cyklonu zmienia kierunek o $180^{\circ}$ i ruchem spiralnym poprzez przewód wylotowy wychodzi z urządzenia 

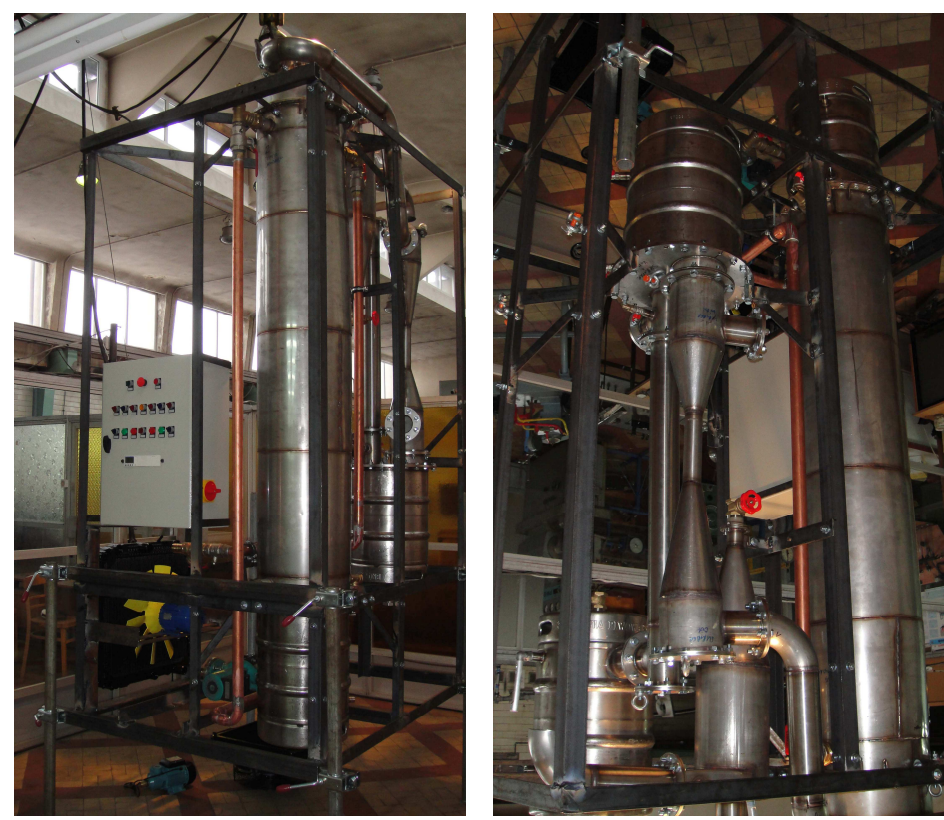

Rys. 3. Widok elementów instalacji oczyszczania gazu

Fig. 3. View of gas cleaning system components

Proces wydzielania cząstek w cyklonie zależy głównie od przyspieszenia dośrodkowego, czas przebywania gazu w cyklonie zależy od założonego profilu przepływu i może zmieniać się od bardzo krótkiego (odpowiadającego wlotowi i wylotowi) do długiego. Podstawową zaletą tego elementu jest prosta i zwarta budowa pozbawiona części ruchomych oraz możliwość pracy w wysokich temperaturach i dużym ciśnieniu. Podstawową wadą jest znaczący spadek ciśnienia gazu niezbędny do skutecznego oczyszczenia. W rozwiązaniu klasycznym, jakie zastosowano w układzie oczyszczania gazu generatorowego, strumień gazu jest wprowadzany stycznie do cylindrycznej części cyklonu.

Kolejnym elementem na drodze oczyszczania gazu generatorowego jest odpylacz mokry czyli skruber. Strumień zasysanego gazu jest oczyszczany wskutek kontaktu z rozpyloną cieczą. W procesie oczyszczania mokrego najczęściej stosowana cieczą jest woda. Stosowane są także płynne węglowodory np. olej napędowy dobrze rozpuszczający smołę. Skruber także bierze udział w procesie schładzania gazu. Strumień gazu jest doprowadzany do skrubera, gdzie zanieczyszczenia z gazu są przenoszone do cieczy. W wyniku burzliwego kontaktu gazu z cieczą tworzą się krople, które są unoszone z gazem oczyszczonym. W celu pozbycia się tego niekorzystnego zjawiska stosuje się odkraplacz. Ciecz z zabsorbowanymi cząstkami zanieczyszczeń w postaci zawiesiny odprowadzana jest ze skrubera i odkraplacza i odprowadzana do separatora. W celu ograniczenia zużycia wody stosuje się układ zamknięty. 
W układzie oczyszczania gazu zastosowano skruber Venturiego z nastawną gardzielą. W tego typu skruberze duża burzliwość i duże prędkości względne gazu i kropel wody decydują o sprawności oczyszczania gazu. Bardzo istotnym parametrem skrubera Venturiego jest długość gardzieli. Ciecz doprowadzana jest za pomocą dysz, które rozpraszają wodę na krople, które są unoszone z gazem do gardzieli. Istotnym parametrem wpływającym na sprawność skrubera jest stosunek objętości cieczy do objętości gazu. Ze wzrostem prędkości gazu maleją rozmiary kropel a wzrasta ich liczba, co zwiększa sprawność oczyszczania. W procesie oczyszczania ciecz odbiera ciepło od jeszcze gorącego gazu, dlatego występuje tu konieczność schładzania cieczy podawanej do dysz skrubera. Układ chłodzenia chłodnicy rurowej jest zamknięty. W przypadku układu chłodzenia skrubera zastosowano układ zamknięty z odprowadzeniem kondensujących zanieczyszczeń.

\section{Wyniki procesu oczyszczania gazu generatorowego}

Badania funkcjonalności instalacji oczyszczającej gaz generatorowy obejmowały m.in.: pomiary składu gazu generatorowego przed i za instalacją oczyszczania oraz pomiary kondensatu (smoła pogazowa i pył) pozyskanego w poszczególnych separatorach instalacji oczyszczającej w czasie ustalonej pracy instalacji zgazowującej. Stabilność procesu zgazowania uzyskiwano po czasie ok. 3h od chwili uruchomienia zgazowarki.
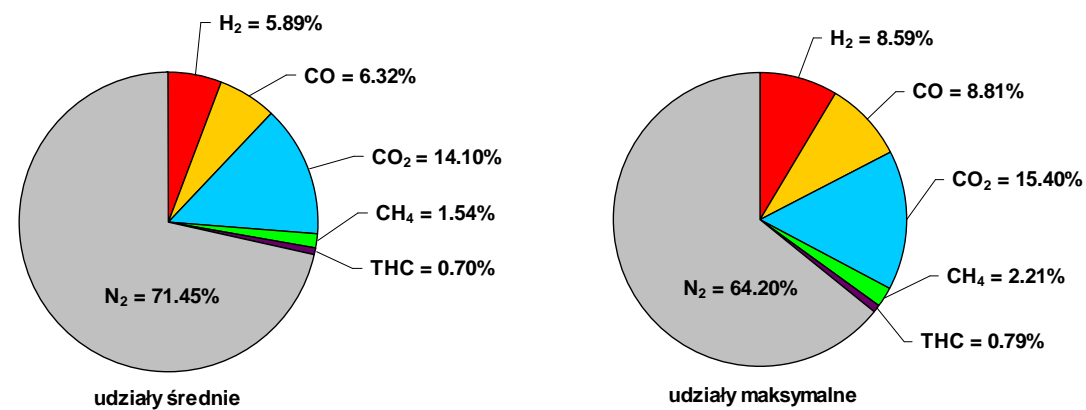

Rys. 4. Skład gazu generatorowego uzyskany w próbie zgazowania osadu ściekowego

Fig. 4. The composition of generator gas obtained by gasification of sewage sludge

Na rysunku 4 przedstawiono między innymi średnie i maksymalne udziały składników palnych wchodzących w skład gazu generatorowego $\left(\mathrm{H}_{2}, \mathrm{CO}, \mathrm{CH}_{4}\right.$, THC) uzyskane w czasie serii pomiarów przeprowadzonych po ostatecznych modernizacjach instalacji zgazowującej osad ściekowy. Na podstawie składu gazu wyznaczono jego wartość opałową $\left(\mathrm{W}_{\mathrm{g}}\right)$ oraz teoretyczne zapotrzebowanie powietrza $\left(\mathrm{L}_{\mathrm{t}}\right)$. Średnie wartości tych wielkości wyniosły $\mathrm{W}_{\mathrm{g}}=2,62 \mathrm{MJ} / \mathrm{m}^{3} \mathrm{i} \mathrm{L}_{\mathrm{t}}=0,67$ $\mathrm{m}^{3} / \mathrm{m}^{3}$ a maksymalne $\mathrm{W}_{\mathrm{g}}=3,51 \mathrm{MJ} / \mathrm{m}^{3} \mathrm{i} \mathrm{L}_{\mathrm{t}}=0,81 \mathrm{~m}^{3} / \mathrm{m}^{3}$.

Instalacja oczyszczająca zapewniła oddzielenie smół pogazowych zawartych w osadzie w stopniu eliminującym kondensację tych smół w układzie dolotowym 
doładowanego silnika tłokowego z chłodnicą sprężonej mieszanki gazu generatorowego $\mathrm{z}$ powietrzem. $\mathrm{W}$ czasie jednej $\mathrm{z}$ przeprowadzonych prób zgazowania osadu trwającej 5,5 godziny ustalonej pracy instalacji zgazowującej z rzeczywistym strumieniem gazu w granicach $3,0 \mathrm{~m}^{3} / \mathrm{min}$ uzyskano gaz o pożądanym składzie (tabela 3) oraz około $24 \mathrm{dm}^{3}$ kondensatu.

Po osiągnięciu stabilnej pracy zgazowarki oraz zadowalającego składu gazu generatorowego przeprowadzono badania silnika spalinowego zasilanego gazem generatorowym oraz olejem napędowym. Badania te są tematem kolejnych publikacji.

\section{Podsumowanie}

Zgazowanie może być skuteczną technologią termicznego przetwarzania przefermentowanych, podsuszonych, organicznych osadów ściekowych, będących ubocznym produktem procesu oczyszczania ścieków komunalnych w oczyszczalni, na energię elektryczną i ciepło. Uzyskany w procesie zgazowania gaz generatorowy, może być z powodzeniem wykorzystany do zasilania silnika tłokowego napędzającego zespół prądotwórczy. Gaz generatorowy oprócz odpowiedniej wartości opałowej, powinien być czysty, pozbawiony pyłu i smoły pogazowej, aby nie wpływać negatywnie na żywotność silnika. Przed doprowadzeniem gazu do silnika musi być on zatem oczyszczony. Doświadczenia eksploatacyjne wielu producentów instalacji zgazowujących pokazują, że systemy oczyszczania gazu nie pracują bezproblemowo i szczególnie w instalacjach małej mocy nie są w stanie zapewnić odpowiedniej czystości gazu.

Zaprezentowana w pracy instalacja oczyszczania gazu generatorowego pozyskanego ze zgazowania osadu ściekowego zapewniła oddzielenie smół pogazowych zawartych w osadzie. Badania kontrolne części układu dolotowego badawczego silnika tłokowego przeprowadzone po ok. 10 godzinach eksploatacji zespołu prądotwórczego zasilanego gazem generatorowym oczyszczonym w zbudowanej instalacji wykazały, że niepożądane zjawisko kondensacji smół pogazowych zostało wyeliminowane w stopniu umożliwiającym wprowadzenie tego gazu do silnika tłokowego.

\section{Literatura}

[1] Ustawa o odpadach. Dz. U nr 62 z 20.06.2001, poz. 629 i Dz. U. nr 7 2003, poz. 78.

[2] Krajowy plan gospodarki odpadami 2010. MP nr 90 z 29.12.2006, poz. 946.

[3] Dyrektywa Rady 1999/31/WE z dnia 26 kwietnia 1999 w sprawie składowania odpadów Dz. Urz. WE L 182 z 16.07.1999.

[4] Dyrektywa Parlamentu Europejskiego i Rady 2009/28/WE z dnia 23.04.2009 r. w sprawie promowania stosowania energii ze źródeł odnawialnych zmieniającej i w następstwie uchylającej Dyrektywy 2001/77/WE oraz 2003/30/WE.

[5] Cupiał K., Jamrozik A., Kociszewski A., Pyrc M., Tutak W., Grab-Rogaliński K.: Instalacja zgazowująca osuszony osad ściekowy, Motrol 2011, Motoryzacja i Energetyka Rolnictwa, tom 13, 2011, s. 80-13. 
[6] Piskowska-Wasiak J.: Oczyszczanie i przetwarzanie gazu ze zgazowania biomasy w celu wytworzenia SNG (Substitute Natural Gas, NAFTA-GAZ, nr 5, 2011, s. 346-360.

[7] Warowny W.: Zgazowanie biomasy. Technologia, Poleko, Poznań, 22 listopada 2007.

[8] Pogoreutz M.: Economical and technological comparision of small-scale CHP on the basis of biomass. $1^{\text {st }}$ World Conference on Biomass for Energy and Industry. Seville 2000.

[9] http://www.deutz.de/ [dostęp 15.10.2014 r.]

[10] http://information.jenbacher.com/ [dostęp 15.10.2014 r.]

[11] Kalina J.: Wytwarzanie ciepła i energii elektrycznej w skojarzeniu w układach rozproszonych małej mocy, zintegrowanych ze zgazowaniem biomasy, Gospodarka Paliwami i Energią, nr 11-12, 2004, s. 15-22.

[12] Tutak W., Jamrozik A.: Generator gas as a fuel to power a diesel engine. Thermal Science, vol. 18, no. 1, 2014, s. 206-216.

[13] Jamrozik A., Tutak W.: Co-firing of generator gas in the generating set with the supercharged diesel engine. Energy Sources, Part A: Recovery, Utilization, and Environmental Effects, przyjęty do druku, 2014

[14] Cupiał K., Pyrc M., Jamrozik A., Tutak W., Kociszewski A.: Problemy oczyszczania gazu generatorowego o dużej zawartości pyłów i smół pogazowych, Silniki Gazowe 2010, nr 183, 2010, s. 189-198.

\title{
CLEANING AND PROCESSING OF GENERATOR GAS FROM GASFICATION WASTE
}

\begin{abstract}
S u m m a r y
Energy from waste is not only a valuable source of renewable energy, but also extremely useful and costeffective method of reducing the amount of waste deposited in landfills. One of methods of neutralization and energetic utilization of waste is technology of gasification and the use of acquired generator gas to power internal combustion engines in power generating sets. When using generator gas to power a piston engine you should remember about the relatively stringent requirements for gas purity. The main problem which occurs in gasification systems are tar products which condense and settle on the inner surfaces of the intake manifold of the engine. They block the flow and timing system components preventing proper operation of the engine. Furthermore, the gas pitch containing chemical compounds can cause corrosion and erosion of the engine cylinder wall. The study characterized the selected technologies of gasification of waste and gas rectification as well as generator gas cleaning set obtained from gasification of sewage sludge that is a by-product of the process in municipal wastewater treatment plant. Cleaning system assured separation of after-gas tars contained in the sediment to the extent eliminating the condensation of these tars in the intake system of supercharged piston engine. The article characterizes the process of gasification which is an example of thermal neutralization of waste and cleaning process gas from gasification generator. Presented running at the Institute of Thermal Machinery Czestochowa University of Technology purification plant generator gas obtained from gasification of sewage sludge that is a byproduct of the process of wastewater treatment in sewage. In the gasification unit of sewage sludge to the gas cleaning system used cyclone filters and Venturi scrubbers. The generator gas cleaning system allowed the separation of gas pitch in the sludge and prevented the condensation of tars in the intake test supercharged piston engine.
\end{abstract}

Keywords: gasification, gas generator, sewage sludge, cleaning system, internal combustion engine

Przestano do redakcji: 13.11.2014 r.

Przyjęto do druku: 22.06.2015 $r$.

DOI:10.7862/rb.2015.45 